\title{
LEUKOCYTE DEPLETION RESULTS IN IMPROVED LUNG FUNCTION AND REDUCED INFLAMMATORY RESPONSE AFTER CARDIAC SURGERY
}

Y. J. Gu, MD, $\mathrm{PhD}^{\mathrm{a}}$

A. J. deVries, $\mathrm{MD}^{\mathrm{b}}$

P. W. Boonstra, MD, PhD

W. van Oeveren, $\mathrm{PhD}^{\mathrm{a}}$
Leukocyte depletion during cardiopulmonary bypass has been demonstrated in animal experiments to improve pulmonary function. Conflicting results have been reported, however, with clinical depletion by arterial line filter of leukocytes at the beginning of cardiopulmonary bypass. In this study, we examined whether leukocyte depletion from the residual heartlung machine blood at the end of cardiopulmonary bypass would improve lung function and reduce the postoperative inflammatory response. Thirty patients undergoing elective heart operations were randomly allocated to a leukocyte-depletion group or a control group. In the leukocyte-depletion group ( $n=20$ ), all residual blood $(1.2$ to $2.1 \mathrm{~L}$ ) was filtered by leukocyteremoval filters and reinfused after cardiopulmonary bypass, whereas in the control group an identical amount of residual blood after cardiopulmonary bypass was reinfused without filtration $(n=10)$. Leukocyte depletion removed more than $97 \%$ of leukocytes from the retransfused blood $(p<$ 0.01) and significantly reduced circulating leukocytes $(p<0.05)$ and granulocytes $(p<0.05)$ compared with the control group. Levels of the inflammatory mediator thromboxane $B_{2}$ determined at the end of operation $(p<0.05)$ were significantly lower in the depletion group than in the control group, whereas no statistical differences in interleukin-6 levels were found between the two groups. After operation, pulmonary gas exchange function (arterial oxygen tension at a fraction of inspired oxygen of 0.4 ) was significantly higher in the leukocyte-depletion group 1 hour after arrival to the intensive care unit $(p<0.05)$ and after extubation $(p<0.05)$. There were no statistical differences between the two groups with respect to postoperative circulating platelet levels and blood loss, and no infections were observed during the whole period of hospitalization. These results suggest that leukocyte depletion of the residual heart-lung machine blood improves postoperative lung gas exchange function and is safe for patients who are expected to have a severe inflammatory response after heart operations. (J Thorac Cardiovasc Surg 1996;112:494-500)
C ardiopulmonary bypass (CPB) induces a wholebody inflammatory response that leads to postoperative lung dysfunction. ${ }^{1,2}$ This response is largely mediated by the activation of polymorpho-

From the Departments of Cardiothoracic Surgery and Anesthe-

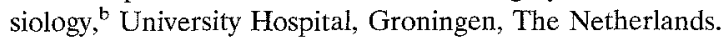

Received for publication Sept. 19, 1995; revisions requested Nov. 21, 1995; revisions received Dec. 14, 1995; accepted for publication Dec. 21, 1995

Address for reprints: W. van Oeveren, $\mathrm{PhD}$, Blood Interaction Research, Department of Cardiothoracic Surgery, University Hospital Groningen, 59 Oostersingel, 9713 EZ Groningen, The Netherlands.

Copyright $\mathbb{C} 1996$ by Mosby-Year Book, Inc.

$0022-5223 / 96 \$ 5.00+0 \quad \mathbf{1 2 / 1 / 7 1 4 4 9}$ nuclear leukocytes and by subsequent leukocyte deposition and interaction with the lung endothelium. ${ }^{3-7}$ During the initial phase of $\mathrm{CPB}$, leukocytes are activated by contact of blood with foreign materials in the extracorporeal circuit. After release of the aortic crossclamp in the late phase of $\mathrm{CPB}$, when heart and lungs are reperfused, activation of leukocytes and leukocyte-endothelium interaction are intensified, leading to the impairment of lung function and the induction of a postoperative inflammatory response known as the "postperfusion syndrome. $.8,9$

Leukocyte depletion by means of filtration was originally used by blood banks to prevent transfusion complications associated with donor leuko- 
cytes. ${ }^{10,11}$ Recent animal experiments demonstrated that leukocyte depletion in different heart operation models reduces heart and lung reperfusion injury. ${ }^{12-14}$ Conflicting results have been noted, however, in reports of clinical use at the beginning of $\mathrm{CPB}$ of arterial line filters with leukocyte-depleting capacity. ${ }^{15-19}$ Furthermore, there has been concern regarding the simultaneous removal of platelets during leukocyte depletion, which could influence postoperative hemostasis. ${ }^{13,20}$

In this article, we report a study in which only the blood residual in heart-lung machine was depleted of leukocytes, because this blood contains a considerable number of activated leukocytes and is usually reinfused to patients immediately after CPB. We examined whether leukocyte depletion of the residual blood at the end of CPB would improve postoperative lung function and reduce the postoperative inflammatory response. We also examined whether such a "partial" leukocyte-depletion method would minimize the major side effect of leukocyte depletion in patients undergoing heart operations, reduction of circulating platelets.

\section{Patients and methods}

Patients. After approval by the medical ethical committee in the University Hospital in Groningen and informed consent from patients, 30 patients electively undergoing either coronary artery bypass grafting, heart valve replacement, or a combined procedure were randomly allocated to a leukocyte-depletion group $(n=20)$ or a control group $(n=10)$. Exclusion criteria were a history of allergy or recurrent infection, reoperation, and emergency operation. The demographic data of patients in both groups are summarized in Table I.

Anesthesia was induced and maintained by intravenous infusion of sufentanil citrate ( 1 to $3 \mu \mathrm{g} / \mathrm{kg}$ ) and midazolam $(0.05$ to $0.1 \mathrm{mg} / \mathrm{kg})$. Muscle relaxation was achieved with pancuronium bromide (100 to $140 \mu \mathrm{g} / \mathrm{kg}$ ). Cefamandol at a dose of $2 \mathrm{gm}$ and dexamethason at a dose of $1 \mathrm{mg} / \mathrm{kg}$ were administered after induction. Anticoagulation was achieved by intravenous administration of bovine lung heparin at a dose of $300 \mathrm{IU} / \mathrm{kg}$ about 5 minutes before the start of CPB.

CPB. The extracorporeal circuit consisted of roller pumps (Stöckert Instrumente GMBH, Munich, Germany) and a microporous polypropylene membrane oxygenator (CML Excel; Cobe Laboratories Inc., Lakewood, Colo.). Within 10 minutes of CPB initiation at a flow rate at $2.4 \mathrm{~L} \times \min ^{-1} \cdot \mathrm{m}^{2}$, the aorta was crossclamped and $1 \mathrm{~L}$ St. Thomas' cardioplegic solution $\left(4^{\circ} \mathrm{C}\right)$ was infused into the aortic root to provide myocardial preservation. During $\mathrm{CPB}$, moderate hypothermia was induced to maintain the nasopharyngeal temperature between $28^{\circ}$ to $30^{\circ} \mathrm{C}$. The mean arterial pressure was maintained at 50 to $60 \mathrm{~mm} \mathrm{Hg}$ during $\mathrm{CPB}$. Anticoagulation during $\mathrm{CPB}$ was monitored by the Celite activated clotting time (International Tech-
Table I. Patient demographic information

\begin{tabular}{lcc}
\hline & $\begin{array}{c}\text { Control } \\
(n=10)\end{array}$ & $\begin{array}{c}\text { Depletion } \\
(n=20)\end{array}$ \\
\hline Age (yr) & $62 \pm 13$ & $60 \pm 11$ \\
Sex (n) & 8 & \\
$\quad$ Male & 2 & 14 \\
Female & $173 \pm 8$ & $172 \pm 10$ \\
Height (cm) & $80 \pm 14$ & $77 \pm 11$ \\
Weight (kg) & $1.97 \pm 0.22$ & $1.91 \pm 0.16$ \\
Body surface $\left(\mathrm{m}^{2}\right)$ & 8 & 14 \\
CABG $(n)$ & - & 5 \\
AVR $(n)$ & 1 & - \\
MVR $(n)$ & 1 & - \\
CABG + AVR $(n)$ & - & 1 \\
CABG + MVR $(n)$ & - & \\
\hline
\end{tabular}

Values expressed as mean \pm standard deviation of the mean. $C A B G$, Coronary artery bypass grafting; $A V R$, aortic valve replacement; $M V R$, mitral valve replacement.

nidyne Co., Edison, N.J.). After CPB, heparin was neutralized by protamine chloride $(3 \mathrm{mg} / \mathrm{kg}$ ).

Leukocyte depletion. Leukocyte depletion was achieved with leukocyte-removal filters (RC400; Pall Biomedical, Portsmouth, U.K.) designed particularly for leukocyte filtration under high-flow conditions in the operating room. ${ }^{21}$ After termination of CPB, a total volume of 1200 to $2100 \mathrm{ml}$ residual blood in the extracorporeal circuit was collected into a blood transfusion bag. In the leukocyte-depletion group, the collected blood was filtered by two or three filters and reinfused before the end of operation, whereas in the control group the residual blood was reinfused through the venous transfusion line without leukocyte filtration.

Lung function. Pulmonary gas exchange was measured by the partial arterial oxygen pressure from blood samples drawn from the radial artery line and standardized at a fraction of inspired oxygen of 0.4. Pulmonary hemodynamics, exemplified by mean pulmonary artery pressure (PAP) and pulmonary capillary wedge pressure (PCWP), were measured through a Swan-Ganz catheter (Baxter Healthcare Corp., Edwards Division, Irvine, Calif.) introduced percutaneously through the right internal jugular vein into the pulmonary artery. Pulmonary vascular resistance (PVR) was calculated according to the following formula: PVR $\left(\right.$ dyne $\left.\cdot \sec \cdot \mathrm{cm}^{-5}\right)=(\mathrm{PAP}-\mathrm{PCWP}) / \mathrm{CO} \times 80$.

Other clinical parameters. Duration of postoperative intubation was recorded during each patient's stay in the intensive care unit. Blood loss was indicated by 24 -hour chest drainage. In addition, durations of stay in the intensive care unit and of hospitalization after operation were obtained from hospital registration records.

Laboratory parameters. For laboratory hematologic tests and biochemical assays, blood samples were taken from the indwelling radial arterial catheter at the baseline before operation, at the end of CPB before transfusion of the leukocyte-depleted blood, at the end of operation during skin closure, 1 hour and 3 hours after the patient's arrival in the intensive care unit, and at 6 AM the next day in the intensive care unit. In addition, prefiltration and postfiltration samples were taken from the transfusion 


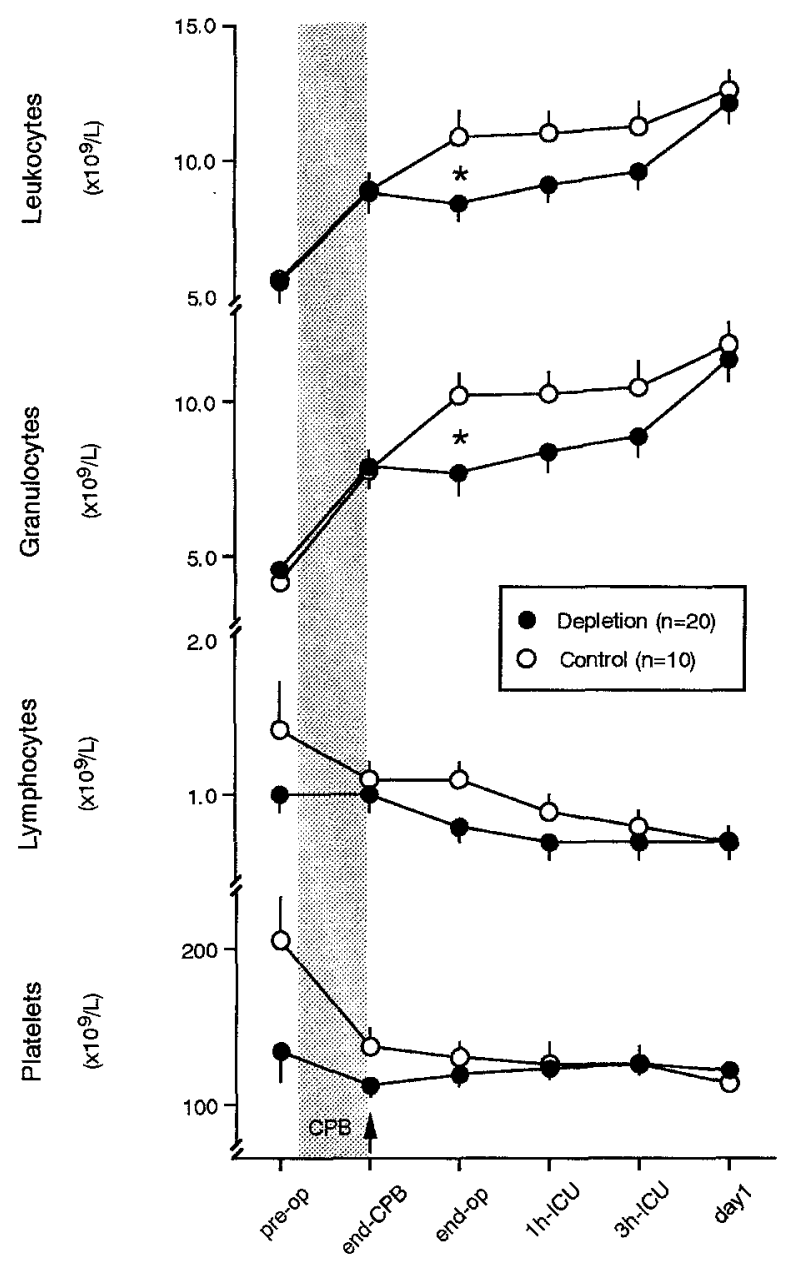

Fig. 1. Circulating leukocytes, granulocytes, lymphocytes and platelets in patients with and without leukocyte depletion of the reinfused heart-lung machine blood after the end of CPB. Arrow indicates the start of depletion; asterisk represents $p<0.05$ between the two groups. pre-op, Before operation; end-op, at end of operation during skin closure; $I C U$, intensive care unit.

bags to determine the cell counts and calculate the rate of leukocyte removal.

Cell counts were determined by a cell counter (CellDyn 610; Abbot, Santa Clara, Calif.) with a dilution of 1:250 for counting leukocytes and granulocytes and of $1: 25,000$ for counting platelets. For the postfiltration samples, leukocytes were counted by means of a Nageotte manual counting chamber or by the cell counter with a dilution of 1:100.

For biochemical assays, plasma was obtained by centrifugation of whole blood at $1100 \mathrm{~g}$ and stored at $-80^{\circ} \mathrm{C}$ for further determinations. Thromboxane was determined by enzyme immunoassay (Cayman Chemical Company, Ann Arbor, Mich.) in plasma anticoagulated with citrate and indomethacin. Interleukin- 2 and interleukin- 6 were deter-

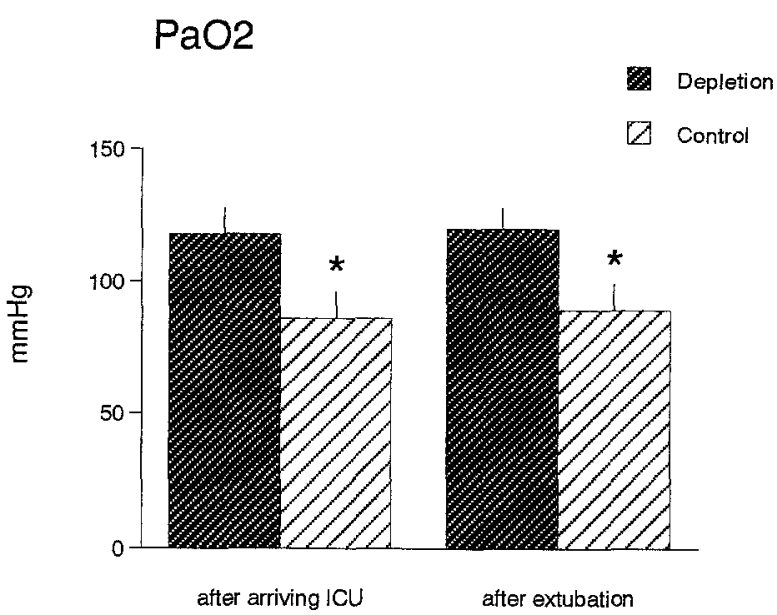

Fig. 2. Arterial partial oxygen pressure $\left(\mathrm{PaO}_{2}\right)$ determined after arrival in the intensive care unit (ICU) and after extubation in patients receiving leukocyte-depleted residual blood $(n=20)$ and in patients receiving nondepleted residual blood $(n=10)$. The fraction of inspired oxygen was standardized at $40 \%$. Asterisk represents $p<$ 0.05 between the two groups.

mined by enzyme immunoassay (Quantikine; R\&D Systems Inc., Minneapolis, Minn.) from citrated plasma.

Statistics. Data processing and statistical tests were performed with StatView software (Abacus Concepts, Inc., Berkeley, Calif.) Data are expressed as mean plus or minus standard error of the mean unless otherwise indicated. A repeated-measures analysis of variance was used to determine the difference between the two groups. Student's $t$ test or Mann-Whitney test was used for analysis of differences between the two groups at each sampling or recording time point. A $p$ value less than 0.05 was considered statistically significant.

\section{Results}

There were no significant differences between the leukocyte-depletion group and the control group with respect to duration of CPB and aortic crossclamp time. All patients recovered uneventfully after operation.

Leukocyte reduction in residual machine blood. The average leukocyte count in the residual machine blood before filtration was $5.76 \pm 0.44 \times 10^{9}$ cells $/ \mathrm{L}$. After filtration, the count was $0.152 \pm$ $0.01 \times 10^{9}$ cells $/ \mathrm{L}$. More than $97 \%$ of the leukocytes were removed from the residual blood in the leukocyte-depletion group. The average platelet count from the machine blood before filtration was $107 \pm$ $6 \times 10^{9}$ cells $/ \mathrm{L}$; after filtration, it was $43 \pm 2 \times 10^{9}$ cells $/ \mathrm{L}$. About $60 \%$ of the platelets in the machine 
Table II. Inflammatory mediators before and after operation

\begin{tabular}{|c|c|c|c|c|c|c|}
\hline Parameter & Before $C P B$ & End $C P B$ & End operation & $I C U 1 \mathrm{hr}$ & $I C U 3 \mathrm{hr}$ & $P O D 1$ \\
\hline \multicolumn{7}{|c|}{ Thromboxane $(\mathrm{pg} / \mathrm{ml})$} \\
\hline Depletion & ND & $48 \pm 15$ & $48 \pm 9^{*}$ & $33 \pm 7$ & $23 \pm 29$ & $19 \pm 26$ \\
\hline Control & $\mathrm{ND}$ & $62 \pm 96$ & $127 \pm 63$ & $48 \pm 15$ & $59 \pm 56$ & $21 \pm 34$ \\
\hline \multicolumn{7}{|c|}{ Interleukin-6 (pg/ml) } \\
\hline Depletion & $36 \pm 14$ & $126 \pm 96$ & $\mathrm{ND}$ & $393 \pm 116$ & $344 \pm 90$ & $125 \pm 46$ \\
\hline Control & $20 \pm 24$ & $197 \pm 246$ & ND & $208 \pm 103$ & $260 \pm 38$ & $155 \pm 29$ \\
\hline \multicolumn{7}{|c|}{ Interleukin-2 (pg/ml) } \\
\hline Depletion & UD & UD & ND & $\mathrm{UD}$ & UD & UD \\
\hline Control & UD & UD & ND & UD & UD & UD \\
\hline
\end{tabular}

Values are expressed as the geometric mean and the standard error of the mean. $I C U$, Intensive care unit; $P O D$, postoperative day; $N D$, not determined; $U D$, undetectable (below the lowest detectable level stated by the manufacturer).

" $p<0.05$ compared with control.

Table III. Pulmonary hemodynamics

\begin{tabular}{lcccc}
\hline$\quad$ Parameter & $\begin{array}{c}\text { Before } \\
C P B\end{array}$ & $\begin{array}{c}\text { End } \\
C P B\end{array}$ & AP & $\begin{array}{c}\text { End } \\
\text { operation }\end{array}$ \\
\hline $\begin{array}{l}\text { PAP (mm Hg) } \\
\text { Depletion }\end{array}$ & $16 \pm 1.1$ & $17 \pm 1.0$ & $14 \pm 1.4$ & $17 \pm 1.1$ \\
$\quad$ Control & $17 \pm 0.9$ & $20 \pm 0.7$ & $19 \pm 0.7$ & $21 \pm 1.0$ \\
PCWP (mm Hg) & & & & \\
$\quad$ Depletion & $10 \pm 0.9$ & $12 \pm 1.4$ & $10 \pm 1.5$ & $10 \pm 1.2$ \\
$\quad$ Control & $12 \pm 0.7$ & $13 \pm 1.1$ & $11 \pm 0.9$ & $14 \pm 1.3$ \\
PVR & & & & \\
$\quad\left(\right.$ dyne $\left.\cdot \mathrm{sec}^{-1} \cdot \mathrm{cm}^{-5}\right)$ & & & & \\
$\quad$ Depletion & $156 \pm 34$ & $129 \pm 32$ & $120 \pm 23$ & $173 \pm 25$ \\
Control & $145 \pm 18$ & $116 \pm 22$ & $103 \pm 15$ & $125 \pm 14$ \\
\hline
\end{tabular}

$A P$, After protamine. Values expressed as mean \pm standard error of the mean.

blood were removed by the filters in the leukocytedepletion group.

Circulating leukocytes and platelets. Circulating leukocyte and granulocyte counts at the end of operation were significantly less in the depletion group than in the control group $(p<0.05)$. There were no significant differences in circulating lymphocyte and platelet counts between the two groups (Fig. 1).

Inflammatory mediators. Thromboxane $B_{2}$ levels were significantly lower in the leukocyte-depletion group than in the control group at the end of operation $(p<0.05$; Table II). Interleukin- 6 levels increased in both the leukocyte-depletion and control groups during the early postoperative period. No significant difference was found between the two groups. Interleukin-2 was not detectable in any of the samples.

Lung function. Pulmonary gas exchange, measured by partial arterial oxygen pressure, was significantly higher in the leukocyte-depletion group than in the control group both at 1 hour after arrival in the intensive care unit $(118 \pm 10$ vs $86 \pm 10 \mathrm{~mm} \mathrm{Hg}$,
Table IV. Perioperative and postoperative data

\begin{tabular}{lrc}
\hline & $\begin{array}{c}\text { Control } \\
(n=10)\end{array}$ & $\begin{array}{c}\text { Depletion } \\
(n=20)\end{array}$ \\
\hline CPB time (min) & $100 \pm 24$ & $94 \pm 38$ \\
Crossclamp time (min) & $67 \pm 19$ & $63 \pm 29$ \\
Blood loss (ml) & $685 \pm 79$ & $587 \pm 87$ \\
Intubation time (hr) & $13.8 \pm 1.3$ & $11.7 \pm 0.9$ \\
ICU stay (days) & $1.1 \pm 0.1$ & $1.0 \pm 0.0$ \\
Hospital stay (days) & $8.7 \pm 2.1$ & $7.3 \pm 0.5$ \\
\hline
\end{tabular}

Values expressed as mean \pm standard deviation of the mean. $I C U$, Intensive care unit.

$p<0.05)$ and immediately after extubation $(120 \pm$ 8 vs $89 \pm 10 \mathrm{~mm} \mathrm{Hg}, p<0.05$; Fig. 2). PAP was somewhat lower in patients receiving leukocytedepleted blood than in the control group, but this difference in PAP was not significant. Similarly, there were no statistical differences in PCWP and PVR between the two groups (Table III).

Other clinical outcomes. There was no significant difference between the two groups with respect to postoperative blood loss recorded from the chest drainage tube until the first postoperative morning. Duration of intubation after operation was slightly shorter in the leukocyte-depletion group than in the control group, but this difference was not statistically significant. Similarly, no statistical difference was found between the two groups regarding the duration of intensive care unit and hospital stays (Table IV).

\section{Discussion}

Leukocyte depletion from systemic circulation during CPB has been reported to reduce free radical-mediated lung injury and granulocyte-mediated ventricular dysfunction in animal experiments. ${ }^{12-14}$ Clinically, however, leukocyte depletion with an arterial line filter at the beginning of CPB has not 
achieved the goals of reducing intraoperative and postoperative leukocytosis and of improving lung function after heart operations. ${ }^{15-19}$ In this study, we have demonstrated that leukocyte depletion of only 1.2 to $2.1 \mathrm{~L}$ residual heart-lung machine blood significantly attenuates postoperative leukocytosis and improves pulmonary gas exchange function in patients undergoing heart operations. Of more importance, because this blood is usually transfused through the venous line without any substantial filtration, leukocyte depletion in this setting may provide a local protective effect for the lungs, even if the amount is relatively small.

There are at least two reasons why leukocyte depletion of the residual heart-lung machine blood may protect the lung. First, we observed in a recent study $^{22}$ that the residual heart-lung machine blood contained higher levels of leukocyte-release products than seen in the systemic circulation, suggesting that the leukocytes remaining in the heart-lung machine are highly activated. Second, it is known that the heart-lung machine blood contains a number of foreign substances, as well as microaggregates formed mainly by platelets and leukocytes. ${ }^{23,}{ }^{24}$ During $\mathrm{CPB}$, the blood is returned to patients from the arterial side of the heart-lung machine, where an arterial line filter removes microaggregates. After $\mathrm{CPB}$, however, the residual heart-lung machine blood is reinfused to patients by intravenous transfusion without any substantial filtration (usually only a clot filter with a large pore size is used). Because the lung is anatomically located to receive all the reinfused blood from the venous side, lung injury may occur as a result of the pulmonary accumulation of microaggregates ${ }^{25,26}$ mediated by trapped platelets and leukocytes.

In fact, current leukocyte-depleting filters remove not only leukocytes but also other particles less than $5 \mu \mathrm{m}$ in diameter. It has been reported recently that a similar type of blood transfusion filter was able to remove the microfibrillar collagen hemostat from the wound blood harvested from the surgical field. ${ }^{27}$ Particulate microaggregates are continuously generated during CPB; this is particularly evident in the cardiotomy return line. ${ }^{23}$ These microaggregates are mostly smaller than $30 \mu \mathrm{m}$ in diameter ${ }^{23}$ and are not always caught by the cardiotomy filter, which usually has a pore size between 20 and $40 \mu \mathrm{m} .{ }^{28}$ Because the residual machine blood collected at the end of CPB contains a large portion of blood from the cardiotomy reservoir, filtration with a leukocyteremoval filter may prevent any particulates larger than $5 \mu \mathrm{m}$ from being retransfused to patient, reducing lung injury.

Although a direct comparison of our results with results obtained from arterial line leukocyte depletion is unjustified, it does appear that leukocyte depletion of the residual machine blood is more likely to have a local effect on protecting the lungs. In addition, leukocyte depletion with transfusion filters may have other advantages in clinical application. The procedure is easy to handle because the filter can be installed at any time before use without flush or priming. Moreover, it could serve as an optional intervention method that can be added at the end of CPB according to the patient's clinical condition, particularly for patients with a longer duration of $\mathrm{CPB}$ and a predicted strong postoperative inflammatory response. One potential disadvantage of this method, however, is the limited blood volume available for filtration, which depends on the volume of residual blood in the heart-lung machine.

The inflammatory mediator thromboxane $B_{2}$ is usually increased during and after CPB in patients undergoing heart operations. ${ }^{29}$ In this study, we observed a significantly reduction of plasma thromboxane $B_{2}$ at the end of operation in the leukocytedepletion group compared with the control group; this difference can be explained by the removal of activated leukocytes and the simultaneous removal of platelets after the end of CPB. We also measured interleukin- 6 and interleukin-2; the former is a marker of acute-phase responise produced by mononuclear phagocytes and the latter is mainly produced by lymphocytes. ${ }^{30}$ We confirmed that the peak release of interleukin- 6 occurred about 1 hour after arrival in the intensive care unit, as reported by other groups. ${ }^{31}$ No significant difference was found between the depletion and the control groups, however, which suggest that leukocyte depletion in this setting has no effect on the release of interleukin- 6 during the early postoperative period. Interleukin-2 was not detectable in any samples, indicating that there was no lymphocyte-associated release of cytokines in these patients. This is in agreement with a recent report that interleukin-2 could be detected only occasionally after heart operations. ${ }^{32}$

One of the concerns regarding leukocyte depletion during heart operations is that the simultaneous removal of platelets ${ }^{13,17}$ might affect postoperative hemostasis. In this study, little influence on circulating platelet count was observed in patients receiving leukocyte-depleted blood, although considerable 
numbers of platelets were removed from the reinfused heart-lung machine blood. Consistently, there was no significant difference between the two groups with respect to the postoperative blood loss. On the other hand, it remains to be elucidated whether removal of platelets from the residual heart-lung machine blood contributed to improved postoperative lung function. It is known that the platelets may deposit in the myocardium during reperfusion, ${ }^{33,34}$ leading to myocardial reperfusion injury. ${ }^{35}$ Moreover, release products from platelets such as platelet activating factor and platelet associated adhesive molecules may further activate leukocytes and promote leukocyte adhesion to the endothelium. ${ }^{36-38}$ This mechanism may also operate in initiating lung injury because platelet deposition occurred similarly during lung reperfusion in the lung microvasculature. $^{39}$

In conclusion, leukocyte depletion of residual heart-lung machine blood at the end of CPB improves postoperative lung gas exchange function and reduces postoperative leukocytosis. Furthermore, leukocyte depletion in this setting did not result in any postoperative complications with respect to hemostasis and infection. Further investigations should be carried out to compare the different leukocyte-depletion methods with respect to clinical benefits and costs, and to determine which patient populations can profit most from this intervention.

We thank the perfusion team and the intensive care unit nursing staff in the Thorax Center, University Hospital Groningen, for collecting the clinical data and J. Haan in the Blood Interaction Research Lab for performing the biochemical assays.

\section{REFERENCES}

1. Kirklin JK, Westaby S, Blackstone EH, Kirklin JW, Chenoweth DE, Pacifico AD. Complement and the damaging effects of cardiopulmonary bypass. J Thorac Cardiovasc Surg 1983;86:845-57.

2. Taggart DP, El-Fiky MM, Carter R, Bowman A, Wheatley DJ. Respiratory dysfunction after uncomplicated cardiopulmonary bypass. Ann Thorac Surg 1993;56:1123-8.

3. van Oeveren W, Kazatchkine MD, Descamps-Latscha B, Maillet F, Fischer E, Carpentier A, et al. Deleterious effects of cardiopulmonary bypass: a prospective study of bubble versus membrane oxygenation. J Thorac Cardiovasc Surg 1985;89:888-99.

4. Gu YJ, van Oeveren W, Boonstra PW, de Haan J, Wildevuur CR. Leukocyte activation with increased membrane expression of CR3 receptors induced by cardiopulmonary bypass. Ann Thorac Surg 1992;53:839-44.

5. Gillinov AM, Bator JM, Zehr KJ, Redmond JM, Burch RM, Ko C, et al. Neutrophil adhesion molecule expression during cardiopulmonary bypass with bubble and membrane oxygenators. Ann Thorac Surg 1993;56:847-53.

6. Kappelmayer J, Bernabei A, Gikakis N, Edmunds LH Jr, Colman RW. Upregulation of Mac-1 surface expression on neutrophils during simulated extracorporeal circulation. $\mathrm{J}$ Lab Clin Med 1993;121:118-26.

7. Dreyer WJ, Michael LH, Millman EE, Berens KL. Neutrophil activation and adhesion molecule expression in a canine model of open heart surgery with cardiopulmonary bypass. Cardiovasc Res 1995;29:775-81.

8. Butler J, Rocker GM, Westaby S. Inflammatory response to cardiopulmonary bypass. Ann Thorac Surg 1993;55:552-9.

9. Kirklin JK. Prospects for understanding and eliminating the deleterious effects of cardiopulmonary bypass [editorial]. Ann Thorac Surg 1991;51:529-31.

10. Lane TA, Anderson KC, Goodnough LT, Kurtz S, Moroff G, Pisciotto PT, et al. Leukocyte reduction in blood component therapy. Ann Intern Med 1992;117:151-62.

11. Eisenfeld L, Silver H, McLaughlin J, Klevjer-Anderson P, Mayo D, Anderson J, et al. Prevention of transfusionassociated cytomegalovirus infection in neonatal patients by the removal of while cells from blood. Transfusion 1992;32: 205-9.

12. Breda MA, Drinkwater DC, Laks $\mathrm{H}$, Bhuta $\mathrm{S}$, Corno AF, Davtyan $\mathrm{HG}$, et al. Prevention of reperfusion injury in the neonatal heart with leukocyte-depleted blood. J Thorac Cardiovasc Surg 1989;97:654-65.

13. Bando K, Pillai R, Cameron DE, Brawn JD, Winkelstein JA, Hutchins GA, et al. Leukocyte depletion ameliorates free radical-mediated lung injury after cardiopulmonary bypass. $\mathbf{J}$ Thorac Cardiovasc Surg 1990;99:873-7.

14. Wilson IC, Gardner TJ, DiNatale JM, Gillinov AM, Curtis WE, Cameron DE. Temporary leukocyte depletion reduces ventricular dysfunction during prolonged postischemic reperfusion. J Thorac Cardiovasc Surg 1993;106:805-10.

15. Allen SM, Pagano D, Bonser RS. Pall leukocyte depleting filter during cardiopulmonary bypass [letter]. Ann Thorac Surg 1994;58:1560.

16. Coleman SM, Demastrie L. Leukocyte depletion reduces postoperative oxygen requirements [letter]. Ann Thorac Surg 1994;58:1567-8.

17. Palanzo DA, Manley NJ, Montesano RM, Yeisley GL, Gordon D. Clinical evaluation of the LeukoGuard (LG-6) arterial line filter for routine open-heart surgery. Perfusion 1993;8:489-96.

18. Johnson D, Thomson D, Mycyk T, Burbridge B, Mayers I. Depletion of neutrophils by filter during aortocoronary bypass surgery transiently improves postoperative cardiorespiratory status. Chest 1995;107:1253-9.

19. Mihaljevic T, Tönz M, von Segesser LK, Pasic M, Grob P, Fehr $\mathbf{J}$, et al. The influence of leukocyte filtration during cardiopulmonary bypass on postoperative lung function: a clinical study. J Thorac Cardiovasc Surg 1995;109:1138-45.

20. Al-Ebrahim K, Shafei H. Pall leukocyte depleting filter during cardiopulmonary bypass [letter]. Ann Thorac Surg 1994;58:1560-1.

21. Gu YJ, de Vries AJ, Boonstra PW, van Oeveren W. Clinical performance of a high-efficiency rapid flow leucocyte removal filter for leucocyte depletion of heparinized cardiopulmonary bypass perfusate. Perfusion 1995;10:425-30.

22. Gu YJ, Obster R, Haan J, Gallandat Huet RC, Eijgelaar A, van Oeveren W. Biocompatibility of leukocyte removal filters 
during leukocyte filtration of cardiopulmonary bypass perfusate. Artif Organs 1993;17:660-5.

23. Solis RT, Noon GP, Beall AC, DeBakey ME. Particulate microembolism during cardiac operation. Ann Thorac Surg 1974;17:332-44.

24. Edmunds LH Jr, Williams W. Microemboli and the use of filters during cardiopulmonary bypass. In: Utley JR, editor. Pathophysiology and techniques of cardiopulmonary bypass, vol 2. Baltimore: Williams \& Wilkins, 1983:101-4.

25. Patterson RH Jr, Twichell JB. Disposable filter for microemboli: use in cardiopulmonary bypass and massive transfusion. JAMA 1971;205:76-80.

26. Durtschi MB, Haisch CE, Reynolds L, Pavlin E, Kohler TR, Heimbach DM, et al. Effect of micropore filtration on pulmonary function after massive transfusion. Am J Surg 1979;138:8-14.

27. Orr MD, Ferdman AG, Maresh JG. Removal of avitene microfibrillar collagen hemostat by use of suitable transfusion filters. Ann Thorac Surg 1994;57:1007-11.

28. Joffe SD, Silvay G. The use of microfiltration in cardiopulmonary bypass. J Cardiothorac Anesth 1994;8:685-92.

29. Faymonville ME, Deby-Dupont G, Larbuisson R, Deby C, Bodson L, Limet R, et al. Prostaglandin E2, prostacyclin, and thromboxane changes during nonpulsatile cardiopulmonary bypass in humans. J Thorac Cardiovasc Surg 1986;91:858-66.

30. Ertel W, Faist E, Nestle C, Hueltner L, Storck M, Schildberg FW. Kinetics of interleukin- 2 and interleukin- 6 synthesis following major mechanical trauma. J Surg Res 1990;48:622-8.

31. Butler J, Chong GL, Baigrie RJ, Pillai R, Westaby S, Rocker GM. Cytokine response to cardiopulmonary bypass with membrane and bubble oxygenation. Ann Thorac Surg 1992; 53:833-8.
32. Perttilä JT, Salo MS, Jalonen JR, Kuttila KT, Viinamäki O, Pulkki KJ. Blood transfusion with autologous and leukocytedepleted or standard allogeneic red blood cells and the immune response to open heart surgery. Anesth Analg 1994;79:654-60.

33. Rosenbaum D, Levitsky S, Silverman N, Kohler J, Lipowski J, LeBreton G, et al. Cardioplegia does not prevent reperfusion injury induced by intracoronary platelet deposition. Circulation 1983;68(3 Pt 2):II102-6.

34. Teoh K, Christakis G, Weisel R, Mullen JC, Madonik MM, Ivanov $\mathrm{J}$, et al. Prevention of myocardial platelet deposition and thromboxane release with dipyridamole. Circulation 1986;74(5 Pt 2):III145-52.

35. Feinberg H, Rosenbaum DS, Levitsky S, Silverman NA, Kohler J, LeBreton G. Platelet deposition after surgically induced myocardial ischemia: an etiologic factor for reperfusion injury. J Thorac Cardiovasc Surg 1982;84:815-22.

36. Ko W, Hawes AS, Lazenby D, Calvano SE, Shin YT, Zelano $\mathrm{JA}$, et al. Myocardial reperfusion injury: platelet-activating factor stimulates polymorphonuclear leukocyte hydrogen peroxide production during myocardial reperfusion. $\mathbf{J}$ Thorac Cardiovase Surg 1991;102:297-308.

37. Weyrich AS, Ma XL, Lefer DJ, Albertine KH, Lefer AM. In vivo neutralization of P-selectin protects feline heart and endothelium in myocardial ischemia and reperfusion injury. $\mathrm{J}$ Clin Invest 1993;91:2620-9.

38. Komai H, Haworth SG. Effect of cardiopulmonary bypass on the circulating level of soluble GMP-140. Ann Thorac Surg 1994;58:478-82.

39. Martin BA, Dahlby R, Nicholls I, Hogg JC. Platelet sequestration in lung with hemorrhagic shock and reinfusion in dogs. J Appl Physiol 1981;50:1306-12. 